\title{
9
}

\section{Politics and Power in Marine Spatial Planning}

\author{
Wesley Flannery, Jane Clarke, and Benedict McAteer
}

\section{Introduction}

Over the past two decades, increasing industrialisation of the marine environment has intensified competition for marine space. This competition has largely been driven by the rapid growth in number and size of spatially fixed marine industries. For example, in the last decade the average size of European offshore wind farms has increased substantially, from 79.6 MW in 2007 to $493 \mathrm{MW}$ for offshore wind farms under construction in 2017 (Wind Europe 2018). In 2015, the global production of aquaculture products was 106 million tonnes, which has been growing at an average annual rate of $6.6 \%$ since 1995 (FAO 2017). The rapid growth of both these industries has obvious socio-spatial consequences. For example, there is increasing concern that the growth of offshore wind farms will displace other activities such as fishing (Kafas et al. 2018). Current governance regimes are, however, sectoral and disconnected and, therefore, ill-suited for managing the rapid industrialisation of the marine environment and related issues of stakeholder conflict.

Until relatively recently, marine governance was highly fractured. Marine governance was sectorally divided, with different marine activities managed on an individual basis, and spatially fragmented, with the governance of contiguous marine areas (e.g. territorial sea and Exclusive Economic Zone) being divided across a number of agencies. MSP has developed as a place-based,

W. Flannery $(\bowtie) \cdot \mathrm{J}$. Clarke $\bullet$ B. McAteer

School of Natural and Built Environment, Queen's University Belfast, Belfast, UK e-mail:w.flannery@qub.ac.uk 
integrated marine governance approach to address the issues that have arisen from sectoral and fragmented management, including increasing user conflicts (Ehler and Douvere 2009). MSP is also promoted as a means of addressing the democratic deficit within marine governance by providing a mechanism through which all those with a stake in marine management can participate in related decision-making processes (Pomeroy and Douvere 2008). In this way, MSP, as a concept, provides the opportunity to imagine a radically different form of marine governance- one that focuses on understanding the complex nature of stakeholder interactions in the marine environment and implements transparent, democratic decision-making.

While MSP, as a concept, promises to overhaul the existing management regime and introduces a new era of democratic, integrated marine governance, its implementation indicates that MSP, as a practice, fails to address issues of politics and power, blunting its radical potential. MSP has partly failed to achieve its radical potential due to the manner in which it has been promoted by the international community (e.g. UNESCO and EU) and implemented by national governments. Although MSP as a concept holds vast transformative potential, the asocial and apolitical framing of MSP all but nullifies its radical utility. While there undoubtedly remains great potential within MSP, "successful implementation can only come by way of acknowledging and addressing unequal power relations and social injustices" (Tafon 2017, p. 3). A number of marine governance scholars have thus appealed for an increased contribution from the social sciences to MSP research (Ritchie and Ellis 2010; Jay et al. 2012; Smith and Jentoft 2017; Tafon 2017; Kelly et al. 2018). We respond to the call for theoretically informed MSP research by arguing that such research must reconceptualise the role of politics and power within MSP processes, move beyond its asocial and apolitical framings and seek to develop ways through which the radical potential of MSP can be realised.

The next section provides an account of MSP and politics arguing that while MSP should be a deeply political process, it has been depoliticised through the adoption of post-political planning processes. This is followed by a deconstruction of 'rationality' within MSP. We argue that rationality is often a product of power and that MSP must acknowledge how the rationalities that underpin MSP are constructed within existing power relations. The chapter concludes with an overview of areas for further research which we think can contribute to realising a more democratised, progressive form of MSP, including how conceptualising MSP as a boundary object may reveal depoliticisation processes and how the use of citizen science may empower stakeholders to counter hegemonic MSP rationalities. 


\section{Politics and MSP}

Marine governance is a political act through which actors negotiate their understanding of a particular problem. As Hajer (1995) demonstrates in his seminal work on environmental discourse, it is no longer a question of if there is an environmental problem, but more a question of how we frame its consequences and champion particular responses. In attempting to legitimise their understanding of problems, and rationalise particular solutions, actors utilise processes of discursive construction, persuasion and even coercion (Hajer 1995; Oreskes and Conway 2010; Metze 2014). Actors seek to ensure that their interpretation of an environmental problem becomes the dominant one, because the manner in which a problem is discursively constructed favours certain ways of acting, while preventing others (Fischer 2003). The same is true for marine planning. Marine problems and their solutions are constructed through discursive practices in which actors attempt to frame marine problems in their favour and limit the potential for rival discourses to take hold. Therefore, MSP is, first and foremost, a political process constituted by numerous discursive struggles to frame marine issues.

While problematising issues within MSP is a profoundly political act, recent MSP processes appear to be devoid of politics, with the logic of Blue Growth seemingly going unchallenged. This raises some fundamental questions for marine social researchers: How is MSP being depoliticised? Which processes are employed to ensure that MSP preserves the status quo? And how do we recapture the radical potentiality of MSP?

Efforts to depoliticise decision-making have been conceptualised as postpolitical processes (Žižek 1999; Rancière 1999; Mouffe 2005). Post-political processes refer to a situation in which debate and dissensus are increasingly sanitised or co-opted through consensual procedures (Wilson and Swyngedouw 2014). In essence, post-political processes describe a society in which the space of contest or struggle (the political) is increasingly overrun by the promotion of free-market economics and the uncritical adoption of consensual procedures. Post-political practices disempower stakeholders by replacing debate and dissensus with practices of governing concerned with "consensus, agreement, accountancy metrics and technocratic environmental management" (Swyngedouw 2009, p. 604). Post-political practices subsequently frame 'issues' as being beyond politics or as being no longer contestable. Instead, problems are grounded in an all-consuming model of free-market neoliberal capitalism (Wilson and Swyngedouw 2014), the continuation of which becomes the solution to all issues. 
Planning afflicted by the post-political condition has been characterised as suffering from a number of highly interrelated symptoms, which function to remove conflicting alternatives from planning processes. These include the advancement of neoliberal policies, choreographed participation, technocratic managerialism, path dependency and the illusion of progressive change (Swyngedouw 2009, 2010, 2011a, b; Allmendinger and Haughton 2011). While this list is not intended to be exhaustive, it comprises the core symptoms of the post-political condition and can be found in emerging MSP practices (Ritchie 2014; Flannery et al. 2016, 2018; Tafon 2017). In the following sections, we discuss each of these symptoms and illustrate how they are apparent in MSP.

The continuation of a society based on free-market neoliberalism is both an aim and an outcome of post-political planning (Swyngedouw 2007; Purcell 2014; Wilson and Swyngedouw 2014; Beveridge and Koch 2017). Postpolitical processes frame contemporary problems and their solutions within the realm of neoliberal logic. Continued economic progression is positioned as the motivating factor behind all planning decisions (Raco 2014). This logic maintains that the neoliberal model cannot be altered, and the solution to any problems of this organisational structure is to be found within itself. The postpolitical condition is thus a neoliberally motivated art of government, attempting to suppress social orders other than free-market economics (Swyngedouw 2009). In practice, an uncritical neoliberal logic is being developed around MSP, with the dominant discourse framing it as a mechanism for facilitating Blue Growth, reducing the bureaucratic burden on developers and allocating the 'correct' space to industry. Rather than industry learning how to engage with a planning process that should act in the public interest and facilitate sustainable, just use of marine resources, marine planners are told that they "should go out to the sectors and learn to speak their language" (European MSP Platform 2017, p. 30). MSP then becomes a process driven by the logic, language and needs of elite stakeholders rather than by concerns about the public good. The pervasiveness of neoliberal logic allows little room for meaningful discussion about alternative, progressive MSP functions (e.g. environmental justice and coastal poverty alleviation).

Participation processes are carefully choreographed within post-political systems (Allmendinger and Haughton 2012; Raco 2014). In order to maintain a society centred around the promotion of neoliberal logic, post-political planning limits and manages the capacity of stakeholders to participate in decision-making processes. Tokenistic participatory planning is emblematic of the post-political condition (Mouffe 2005; Purcell 2008; Swyngedouw 2009; Ward et al. 2017). Elites choreograph tokenistic participation around a 
restricted vision of a society based on free-market neoliberalism (Swyngedouw 2011b; Raco 2014). To do this, conflicting alternatives are neutralised within participatory processes characterised by asymmetrical power structures (Mouffe 2005). Within these processes, debate is perceived as an unnecessary complication, and the hegemony is consequently legitimised through 'collaborative' procedures (Wilson and Swyngedouw 2014). These critiques of participatory procedures as being choreographed and tokenistic rhyme with analyses of emerging MSP practice. MSP initiatives have been described in evaluations of various initiatives as being a 'top-down' process (Jones et al. 2016), or characterised by centralised decision-making (Scarff et al. 2015), or the repackaging of historic power dynamics (Flannery et al. 2018).

Managerial-technological apparatuses are positioned within post-political planning as being capable of negotiating complex socio-environmental conflicts (Oosterlynck and Swyngedouw 2010). With the purpose of legitimising dominant agendas, social problems within post-political processes are reduced to technical issues to be overcome by experts (Wilson and Swyngedouw 2014). For example, the complexity of social-ecological relations in the marine environment are increasingly simplified through the use of mapping technologies (Smith and Brennan 2012) and captured in geospatial databases (Boucquey et al. 2016), creating problematic conceptualisations of relationships as being fixed and two-dimensional (Steinberg and Peters 2015). These Geographic Information System (GIS) databases are analysed by technical experts to make 'rational' decisions about marine issues that have been disembodied from their social contexts (Vonk et al. 2005). In this manner, MSP has been reduced to a mere technocratic exercise of allocating space in an efficient manner, dulling its potential for envisaging alternative marine futures.

Decisions made within post-political planning are often path dependent. Path dependency is the process of making decisions so that they fit with past decisions (Haughton et al. 2013). The capacity for planning afflicted by the post-political condition to provide a shift from the shortcomings of historic practices is limited, as it too often reapplies previous management paradigms that suit powerful stakeholders. Such restrictive decision-making is apparent within MSP implementation. For example, the fragmented licensing and management regimes, which gave rise to MSP, will remain in place even as EU member states begin to implement MSP.

Post-political planning provides an illusion of progressive change while maintaining the status quo (Allmendinger and Haughton 2011). While narratives of participatory and egalitarian practices stimulate visions of a new era of sustainable and radical planning, the reality of post-political planning is less remarkable (Swyngedouw 2009). Under decisions restricted by neoliberal 
logic, post-political planning fails to provide regime shifts towards sustainable development. By entrenching historic practices, post-political planning simply hides existing power dynamics and their affects behind the rhetoric of progressive change. MSP demonstrates this illusion of progressive change as some nations have merely propagated existing asymmetrical social structures under the pretence of participatory governance and do little more than implement the status quo (Flannery et al. 2016).

Emerging MSP practice contains many of the post-political symptoms outlined earlier. If we are to recover the radical potentials of MSP, research needs to explore the processes used to depoliticise MSP. To achieve this, MSP research needs to examine how and why a wide range of stakeholders' support processes which, according to evaluations, contain very little for them. To do so, researchers must explore how 'rationality' and power have been mobilised to shape particular forms of MSP.

\section{Rationality, Power and MSP}

Rationality and power are central forces within planning practice. These forces are intertwined and, ultimately, shape planning practice in favour of powerful actors. Rationality is offered as an appeal to reason (Flyvbjerg 1998), to accept some form of neutral logic within planning processes. Rationality, however, is context dependent and the context of rationality is power (Flyvbjerg 1998). As such, rationality, in and of itself, can never be viewed as a neutral or unbiased determination, as it will fundamentally be tied to some form of power (Flyvbjerg 1998). The rationalities constructed within planning processes are never impartial, they are "framed on specific, and often unarticulated assumptions and values" that reflect the hegemony or the interests of powerful actors (Flannery et al. 2016, p. 123). Rationality should, therefore, be read as "the legitimizing of power, rather than as a challenge to it" (Jones and Porter 1994, p. 2). As opposed to being a logic that can be deduced from reason alone, rationality is socially constructed within particular contexts which reflect prevailing power relations.

MSP has been presented as a logical idea whose time has come (Ehler 2018) and has been advanced on the basis of at least two main rationalities: (1) the adoption of space as a core component of governance will address issues arising from historic marine management practices; and (2) the adoption of participatory planning will address the democratic deficit in marine governance. However, as outlined earlier, MSP has been bent to suit particular agendas. The logic of these rationalities has been appropriated by powerful actors to 
shape MSP to their needs. To exemplify the interrelationship between rationality and power, we focus on the connection between MSP (as the embodiment of these two rationalities) and Blue Growth (as the embodiment of power).

The adoption of space as a core component of marine governance is viewed as a mechanism that can ensure the sustainability of marine environments by reducing user conflict and cumulative impacts on ecosystems through the "rational organization of the use of marine space" (Douvere 2008, p. 766). The phrase 'rational organisation' advances the idea that there is an unproblematic spatial logic that can be deployed to organise the many actors who compete for locations. This asocial and apolitical conceptualisation of MSP views it as a logical process, sitting above power, which will produce a rational use of marine areas. This logic is based on an uncritical understanding of the complex social processes that produce space, particularly how space is produced by power.

Power, conceptualised here as Blue Growth, deploys this rationality to further its agenda. Blue Growth is "a complex governmental project that opens up new governable spaces and rationalizes particular ways of governing" (Choi 2017, p. 37). Despite claims that it is a sustainable development paradigm, Blue Growth is increasingly grounded in the logics of capitalist growth with little or no attention being given to issues related to social inequalities (Silver et al. 2015). Blue growth problematises marine governance in terms of its capacity to create ocean and marine areas for accumulation (Silver et al. 2015) and structures marine governance around issues related to utility, efficiency and prosperity (Choi 2017). Responding to the Blue Growth agenda, MSP has become a technical issue, focused on the allocation of spaces for accumulation rather than on good governance. Due to the dominance of the Blue Growth discourse within the EU, the problems to be addressed by MSP no longer relate to good environmental governance, but, rather, are concerned with creating the appropriate conditions for the rapid expansion of particular industries. Specifically, these include ocean energy, seabed mining, blue biotechnology, coastal tourism and aquaculture (EC 2014). The marine problem is reduced to ensuring that there is no spatial conflict amongst marine sectors and that the most valuable sectors have access to the spaces they desire. Therefore, rather than being inherently logical, MSP champions a particularly narrow, neoliberal rationality that views space as merely a site of production.

MSP is rationalised as a mechanism for democratising marine governance, which can incorporate the values of all those with a stake in marine ecosystems and, simultaneously, produce consensus and win-win outcomes for 
conflicting stakeholders (Pomeroy and Douvere 2008; Carneiro 2012; White et al. 2012). This is an oversimplified conceptualisation of participatory planning, one that is removed from the realpolitik and exertion of power and influence that permeate natural resource management. The adoption of the logic of participatory planning ignores the way in which powerful actors can use the 'illusion of inclusion' to secure legitimacy for fundamentally undemocratic processes (Purcell 2009). Rather than being a device to overcome democratic deficits, critics of participatory processes argue that "the true purpose of public participation has again become legitimisation rather than involvement in decision-making" (Blowers et al. 2009, p. 312). For critics, these 'legitimatisation' processes are not concerned with strengthening the democratic nature of decision-making, but, rather, are used to co-opt the public into advancing the agendas of elite actors (Flyvbjerg 1998; McGuirk 2001).

Broad-scale participatory processes within MSP processes, wherein stakeholders have little influence, are used to gain legitimacy for Blue Growth objectives. Recent academic evaluations of participation in MSP portray the process as being implemented in a top-down, tokenistic manner, wherein local actors struggle to be valued within decision-making processes (Flannery and Ó Cinnéide 2012; Jones et al. 2016; Jentoft 2017; Smith and Jentoft 2017). These negative evaluations are leading to a growing academic concern "that MSP is not facilitating a paradigm shift towards publicly engaged marine management, and that it may simply repackage power dynamics in the rhetoric of participation to legitimise the agendas of dominant actors" (Flannery et al. 2018, p. 32). Within MSP, relations of power purposefully marginalise particular groups of marine actors and "herd their participation and ways of knowing toward achieving limited policy outcomes" (Tafon 2017, p. 1). Thus, MSP may turn into a 'zero-sum game' (Jones et al. 2016), failing to accomplish some of the democratic goals of 'good governance' which it reportedly aspires to (Jentoft 2017). Therefore, despite all the positivity associated with a shift to a new form of governance, there are growing doubts about MSP's capacity to progress truly democratic processes, particularly as it bends towards serving a narrow Blue Growth agenda.

As Smith and Jentoft (2017, p. 34) assert, "as the theoretical foundation of Marine Spatial Planning was being laid, the issue of power was arguably not sufficiently problematized". MSP, as it is currently operationalised, is neither a neutral nor an objective instrument to decide about conflicting claims. In reality, MSP, like many other systems that measure and organise sociopolitical spaces, may facilitate a model of governance that benefits some to the detriment of others (Jentoft 2017). It would, therefore, be more appropriate to discuss MSP as sites of politics and power (Tafon 2017) that focuses on the 
production of space. Accordingly, MSP scholarship and practice need to develop a relational understanding of marine space (Jay et al. 2012) and must understand how it is socially produced and how this is related to power.

\section{$4 \quad$ Recentring Politics and Power in MSP Research}

MSP offers the potential to reformulate marine governance regimes. There is a fundamental need, therefore, for MSP research to employ theoretical lens which can expose the post-political nature of these planning processes. MSP research needs to explore the processes used to frame MSP so that it favours elite stakeholders. Research must explore why a wide range of stakeholders support MSP processes which, according to evaluations, contain very little for them. To achieve this, issues of politics and power must be brought to the fore in MSP research. Here, we offer two approaches that may help recentre politics and power in MSP research and practice: (1) the adoption of a boundary object lens and (2) citizen science.

\subsection{MSP as a Boundary Object}

A more power conscious assessment of MSP would take account of how issues are framed within MSP processes, asking how do stakeholders and decisionmakers arrive at particular framings, if these are widely accepted and who, if anyone, dominates this process? We suggest that framing MSP negotiations as a boundary object may offer valuable insights into these questions. Star and Griesemer (1989, p. 393) conceptualised 'boundary objects' as objects/things/ concepts "which are both plastic enough to adapt to local needs and the constraints of the several parties employing them, yet robust enough to maintain a common identity". Their state of being does not derive from their materiality or tangibility but, instead, derives from the action that they afford (Star 2010). This facilitative character is exemplified by the role a map of California played within the process to establish the Berkley Museum of Vertebrate Zoology in 1907 (Star and Griesemer 1989). The map, as a boundary object, facilitated collaboration between professional biologists and amateur conservationists. While the map maintained its geo-political boundaries between uses, actors interpreted the internal meaning of the map differently; where professional biologists saw 'life zones', amateur conservationists emphasised trails, campsites and places to collect samples (Star and Griesemer 1989). The 
map's internal ambiguity, but common boundaries, enabled different types of knowledge from distinct actors to be brought together to provide a more complete understanding of the California area. The literature has broadly viewed boundary objects as exclusively facilitating collaboration. Yet by recentralising the role of power, a boundary object must also be understood as providing an illusion of collaboration (Carlile 2002; Oswick and Robertson 2006; Thomas et al. 2007). Such a deceptive role is apparent in Oswick and Robertson's (2006) re-examination of the analysis of public enquiry into the Piper Alpha disaster. ${ }^{1}$ The resulting report acted as a boundary object utilising sense-making narratives similar to other reports to gain legitimacy, whilst reinforcing and legitimising structures of historic governance. Boundary objects must therefore be conceptualised as having the capacity to both enable and inhibit interactions (Hawkins et al. 2017).

We argue that MSP must be viewed as a boundary-spanning object that crosses multiple communities and disciplines and provides a platform through which marine problems are framed. By spanning multiple boundaries, MSP enables a 'common' understanding of these framings to be produced and, ultimately, accepted by a diverse range of communities. However, MSP will not span these communities in a neutral manner, and powerful actors can bend it to suit their needs. Adopting a boundary object lens will provide insights into processes that seek to define MSP so that it both achieves the goals of powerful actors yet remains sufficiently elastic so as to prevent debate and dissensus. Conceptualising MSP as a boundary object—something which brings diverse stakeholders together, which each view from their own perspective, yet negotiate a common understanding of-provides a theoretically driven analysis of the processes through which actors collaborate or act so as to deny the actions of others. Examining MSP in this way will facilitate a greater understanding and explanation of the processes of negotiating, cooption and domination that occur within MSP initiatives.

\subsection{Citizen Science and MSP}

The production and use of knowledge and rationalities within MSP initiatives also need to be examined. This must go beyond identifying power and should explore alternative approaches to knowledge production that could enhance MSP. While knowledge is only one of many resources in the power field, Gaventa and Cornwall (2001) highlight how it, more than any other, determines

${ }^{1}$ Piper Alpha disaster is the world's deadliest oil platform disaster, which resulted in the loss of 167 lives in 1988. 
what is conceived as important. In the simplest of terms, it is knowledge which gives weight and legitimacy to particular rationalities. For instance, discourses of 'technical' or 'expert' knowledge are often utilised as a means of legitimising planning decisions. It is within these discourses that the exercise of power operates (Rose and Miller 1992). What is of most importance here is the manner in which knowledge is used by power. The power-knowledge nexus highlights how we come to understand things as being rational. "Power, quite simply, produces that knowledge and that rationality which is conducive to the reality it wants. Conversely, power suppresses that knowledge and rationality for which it has no use" (Flyvbjerg 1998, p. 36). Effectively, then, power has the ability to pick and choose which knowledge is needed for the particular context in question and, subsequently, produces the necessary rationality to create the desired 'reality'. "In modern societies the ability to facilitate or suppress knowledge is in large part what makes one party more powerful than another" (Flyvbjerg 1998, p. 36). MSP research must analyse how certain knowledges are produced and rationalised by powerful actors in MSP processes. Conversely, it should also explore avenues for the production of alternative knowledge and how it may be used to counter hegemonic thinking.

There appears, therefore, to be scope to examine the potential for an increased focus on stakeholder-driven knowledge production. One such example of this is citizen science. Generally, citizen science is seen as a means of opening up knowledge production. Citizen science in a marine context is not a new means of producing knowledge, yet key social aspects of the approach remain relatively under-examined and may provide avenues for instigating a more radical implementation of MSP. While it is important to examine how citizen science projects function, the types of knowledge they produce and where this knowledge goes, emphasis should also be placed on exploring the potential to view citizen science as a means of changing power balances within structures of marine governance. Changing power relations are exemplified when the knowledge produced by a citizen science project leads to a paradigm shift in marine governance. This may be most evident in a project that leads to an alteration of legislation or policy, but can also be achieved by challenging rationales and dominant discourse.

\section{Conclusions}

The potential of MSP has been lost due to the manner in which it has been translated into practice. MSP is increasingly implemented through postpolitical processes or used by powerful actors to further the Blue Growth agenda. There is a fundamental need to understand how MSP has been 
depoliticised and how power shapes MSP practice. We argue that research needs to go beyond describing MSP as a post-political process or as a site of politics and power, and that there is a need to develop critical MSP social science research that can offer avenues to recapture MSP radical potential. We believe this can be achieved by in-depth research into how objectives for MSP initiatives are negotiated in a seemingly non-political manner. Framing MSP as a boundary object around and through which stakeholders negotiate may offer some insight into this process. We also argue that there needs to be a greater understanding about the use of power and knowledge within MSP processes. Here we argue that there is a need to go beyond identifying how power operates and that there needs to be an exploration of more democratic forms of knowledge production within MSP processes.

Acknowledgements We are grateful to the project "Economy of maritime space" funded by the Polish National Science Centre for contributing the Open Access fee for this chapter and facilitating our discussions and preparation of the book. The contributions from Jane Clarke and Ben McAteer were derived from research funded by the Northern Ireland Department for Economy.

\section{References}

Allmendinger, P., \& Haughton, G. (2012). Post-political Spatial Planning in England: A Crisis of Consensus? Transactions of the Institute of British Geographers, 37(1), 89-103.

Beveridge, R., \& Koch, P. (2017). The Post-political Trap? Reflections on Politics, Agency and the City. Urban Studies, 54(1), 31-43.

Blowers, A., Boersema, J., \& Martin, A. (2009). Whatever Happened to Environmental Politics? Journal of Integrative Environmental Sciences, 6(2), 97-101. https://doi.org/10.1080/19438150902981633.

Boucquey, N., Fairbanks, L., Martin, K. S., Campbell, L. M., \& McCay, B. (2016). The Ontological Politics of Marine Spatial Planning: Assembling the Ocean and Shaping the Capacities of 'Community' and 'Environment'. Geoforum, 75, 1-11.

Carlile, P. R. (2002). A Pragmatic View of Knowledge and Boundaries: Boundary Objects in New Product Development. Institute for Operations Research and the Management Sciences, 13(4), 442-455.

Carneiro, G. (2012). Evaluation of Marine Spatial Planning. Marine Policy, 37, 214-229. https://doi.org/10.1016/j.marpol.2012.05.003.

Choi, Y. R. (2017). The Blue Economy as Governmentality and the Making of New Spatial Rationalities. Dialogues in Human Geography, 7(1), 37-41. https://doi. org/10.1177/2043820617691649. 
Douvere, F. (2008). The Importance of Marine Spatial Planning in Advancing Ecosystem-Based Sea Use Management. Marine Policy, 32, 762-771.

EC. (2014). Infographics: Blue Growth. Retrieved May 2, 2018, from http://ec. europa.eu/maritimeaffairs/policy/blue_growth/infographics/.

Ehler, C. N. (2018). Marine Spatial Planning: An Idea Whose Time Has Come. In Offshore Energy and Marine Spatial Planning. In K. Yates \& C. Bradshaw (Eds.), Offshore Energy and Marine Spatial Planning (pp. 6-17). London: Routledge.

Ehler, C., \& Douvere, F. (2009). Marine Spatial Planning: A Step-by Step Approach Towards Ecosystem-based Management. Manual and Guides No 153 ICAM Dossier No 6. Paris: Intergovernmental Oceanographic Commission UNESCO IOC, 99 pp.

European MSP Platform. (2017). Maritime Spatial Planning for Blue Growth How to Plan for a Sustainable Blue Economy? Final Conference Report. Retrieved May 2, 2018, from http://msp-platform.eu/sites/default/files/20171123_msp4bg_conferencereport_0.pdf.

FAO. (2017). FAO Aquaculture Newsletter, No. 56. Rome: FAO.

Fischer, F. (2003). Reframing Public Policy: Discursive Politics and Deliberative Practices. Oxford University Press.

Flannery, W., \& Ó Cinnéide, M. (2012). Stakeholder Participation in Marine Spatial Planning: Lessons from the Channel Islands National Marine Sanctuary. Society and Natural Resources, 25(8), 727-742.

Flannery, W., Ellis, G., Ellis, G., Flannery, W., Nursey-Bray, M., van Tatenhove, J. P., Kelly, C., Coffen-Smout, S., Fairgrieve, R., Knol, M., \& Jentoft, S. (2016). Exploring the Winners and Losers of Marine Environmental Governance/Marine Spatial Planning: Cui bono?/"More than Fishy Business": Epistemology, Integration and Conflict in Marine Spatial Planning/Marine Spatial Planning: Power and Scaping/Surely Not All Planning Is Evil?/Marine Spatial Planning: A Canadian Perspective/Maritime Spatial Planning-"ad utilitatem omnium"/Marine Spatial Planning: "It Is Better to Be on the Train than Being Hit by It"/Reflections from the Perspective of Recreational Anglers... Planning Theory \& Practice, 17(1), 121-151. https://doi.org/10.1080/14649357.2015.1131482.

Flannery, W., Healy, N., \& Luna, M. (2018). Exclusion and Non-participation in Marine Spatial Planning. Marine Policy, 88, 32-40. https://doi.org/10.1016/j. marpol.2017.11.001.

Flyvbjerg, B. (1998). Rationality and Power: Democracy in Practice. Chicago: University of Chicago Press.

Gaventa, J., \& Cornwall, A. (2001). Power and Knowledge. In P. Reason \& H. Bradbury (Eds.), Handbook of Action Research: Participative Inquiry \& Practice (pp. 70-80). London: Sage Publications.

Hajer, M. A. (1995). The Politics of Environmental Discourse: Ecological Modernization and the Policy Process. New York: Oxford University Press.

Haughton, G., Allmendinger, P., \& Oosterlynck, S. (2013). Spaces of Neoliberal Experimentation: Soft Spaces, Postpolitics, and Neoliberal Governmentality. Environment and Planning A, 45(1), 217-234. 
Hawkins, B., Pye, A., \& Correia, F. (2017). Boundary Objects, Power, and Learning: The Matter of Developing Sustainable Practice in Organizations. Management Learning, 48(3), 292-310.

Jay, S., Klenke, T., Ahlhorn, F., \& Ritchie, H. (2012). Early European Experience in Marine Spatial Planning: Planning the German Exclusive Economic Zone. European Planning Studies, 20(12), 2013-2031.

Jentoft, S. (2017). Small-Scale Fisheries Within Maritime Spatial Planning: Knowledge Integration and Power. Journal of Environmental Policy and Planning, $7200,1-13$.

Jones, C., \& Porter, R. (1994). Reassessing Foucault: Power, Medicine \& the Body. New York: Routledge.

Jones, P. J., Lieberknecht, L., \& Qiu, W. (2016). Marine Spatial Planning in Reality: Introduction to Case Studies and Discussion of Findings. Marine Policy, 71, 256-264. https://doi.org/10.1016/j.marpol.2016.04.026.

Kafas, A., Donohue, P., Davies, I., \& Scott, B. E. (2018). Displacement of Existing Activities. In K. Yates \& C. Bradshaw (Eds.), Offshore Energy and Marine Spatial Planning (pp. 88-112). London: Routledge.

Kelly, C., Ellis, G., \& Flannery, W. (2018). Conceptualizing Change in Marine Governance: Learning from Transition Management. Marine Policy, 95, 24-25.

McGuirk, P. M. (2001). Situating Communicative Planning Theory: Context, Power and Knowledge. Environment and Planning A, 3392, 195-217.

Metze, T. (2014). Fracking the Debate: Frame Shifts and Boundary Work in Dutch Decision Making on Shale Gas. Journal of Environmental Policy and Planning, 19(1), 35-52.

Mouffe, C. (2005). On the Political. Routledge.

Oosterlynck, S., \& Swyngedouw, E. (2010). Noise Reduction: The Postpolitical Quandary of Night Flights at Brussels Airport. Environment and Planning A, 42(7), 1577-1594.

Oreskes, N., \& Conway, E. M. (2010). Defeating the Merchants of Doubt. Nature, 465(7299), 686.

Oswick, C., \& Robertson, M. (2006). Boundary Objects Reconsidered: From Bridges and Anchors to Barricades and Mazes. Journal of Change Management, 9(2), 179-193.

Pomeroy, R., \& Douvere, F. (2008). The Engagement of Stakeholders in the Marine Spatial Planning Process. Marine Policy, 32, 816-822. https://doi.org/10.1016/j. marpol.2008.03.017.

Purcell, M. (2008). Recapturing Democracy: Neoliberalization and the Struggle for Alternative Urban Futures. Routledge.

Purcell, M. (2009). Resisting Neoliberalization: Communicative Planning or Counter-Hegemonic Movements? Planning Theory, 8(2), 140-165. https://doi. org/10.1177/1473095209102232.

Purcell, M. (2014). Rancière and Revolution. Space and Polity, 18(2), 168-181.

Raco, M. (2014). The Post-politics of Sustainability Planning: Privatisation and the Demise of Democratic Government. In J. Wilson \& E. Swyngedouw (Eds.), The 
Post-political and Its Discontents (pp. 25-47). Edinburgh: Edinburgh University Press.

Rancière, J. (1999). Disagreement: Politics and Philosophy. Minneapolis: University of Minnesota Press.

Ritchie, H. (2014). Understanding Emerging Discourses of Marine Spatial Planning in the UK. Land Use Policy, 38, 666-675.

Ritchie, H., \& Ellis, G. (2010). A System that Works for the Sea? Exploring Stakeholder Engagement in Marine Spatial Planning. Journal of Environmental Planning and Management, 53(6), 701-723. https://doi.org/10.1080/09640568. 2010.488100.

Rose, N., \& Miller, P. (1992). Political Power Beyond the State: Problematics of Government. The British Journal of Sociology, 43, 173-205.

Scarff, G., Fitzsimmons, C., \& Gray, T. (2015). The New Mode of Marine Planning in the UK: Aspirations and Challenges. Marine Policy, 51, 96-102.

Silver, J. J., Gray, N. J., Campbell, L. M., Fairbanks, L. W., \& Gruby, R. L. (2015). Blue Economy and Competing Discourses in International Oceans Governance. The Journal of Environment \& Development, 24(2), 135-160. https://doi. org/10.1177/1070496515580797.

Smith, G., \& Brennan, R. E. (2012). Losing Our Way with Mapping: Thinking Critically About Marine Spatial Planning in Scotland. Ocean and Coastal Management, 69, 210-216.

Smith, G., \& Jentoft, S. (2017). Marine Spatial Planning in Scotland. Levelling the Playing Field? Marine Policy, 84, 33-41. https://doi.org/10.1016/j. marpol.2017.06.024.

Star, S. (2010). This Is Not a Boundary Object: Reflections on the Origin of a Concept. Science, Technology, \& Human Values, 35(5), 601-617. Retrieved from http://journals.sagepub.com/doi/10.1177/0162243910377624.

Star, S. L., \& Griesemer, J. R. (1989). Institutional Ecology, 'Translations' and Boundary Objects: Amateurs and Professionals in Berkeley's Museum of Vertebrate Zoology, 1907-39. Social Studies of Science, 19(3), 387-420.

Steinberg, P., \& Peters, K. (2015). Wet Ontologies, Fluid Spaces: Giving Depth to Volume Through Oceanic Thinking. Environment and Planning D: Society and Space, 33(2), 247-264.

Swyngedouw, E. (2007). Impossible "Sustainability" and the Post Political Condition. In R. Krueger \& D. Gibbs (Eds.), The Sustainable Development Paradox: Urban Political Economic in the United States and Europe (pp. 13-40). London: Guilford Press.

Swyngedouw, E. (2009). The Antinomies of the Postpolitical City: In Search of a Democratic Politics of Environmental Production. International Journal of Urban and Regional Research, 33(3), 601-620.

Swyngedouw, E. (2010). Apocalypse Forever? Post-political Populism and the Spectre of Climate Change. Theory, Culture \& Society, 27(2-3), 213-232. 
Swyngedouw, E. (2011a). Depoliticized Environments: The End of Nature, Climate Change and the Post-Political Condition. Royal Institute of Philosophy Supplement, 69(October), 253-274.

Swyngedouw, E. (2011b). Interrogating Post-democratization: Reclaiming Egalitarian Political Spaces. Political Geography, 30(7), 370-380.

Tafon, R. V. (2017). Taking Power to Sea: Towards a Post-structuralist Discourse Theoretical Critique of Marine Spatial Planning. Environment and Planning C: Politics and Space, 36(2), 1-16. https://doi.org/10.1177/2399654417707527.

Thomas, R., Hardy, C., \& Sargent, L. D. (2007). Artifacts in Interaction: The Production and Politics of Boundary Objects. Advanced Institute of Management Research Paper No. 052 (p. 50). Advanced Institute of Management Research, London.

Vonk, G., Geertman, S., \& Schot, P. (2005). Bottlenecks Blocking Widespread Usage of Planning Support Systems. Environment and Planning A, 37(5), 909-924.

Ward, L., Anderson, M. B., Gilbertz, S. J., McEvoy, J., \& Hall, D. M. (2017). Public Stealth and Boundary Objects: Coping with Integrated Water Resource Management and the Post-political Condition in Montana's Portion of the Yellowstone River Watershed. Geoforum, 83, 1-13.

White, C., Halpern, B. S., \& Kappel, C. V. (2012). Ecosystem Service Trade-Off Analysis Reveals the Value of Marine Spatial Planning for Multiple Ocean Uses. Proceedings of the National Academy of Sciences, 109(12), 4696-4701. https://doi. org/10.1073/pnas.1114215109.

Wilson, J., \& Swyngedouw, E. (2014). Seeds of Dystopia: Post-politics and the Return of the Political. In J. Wilson \& E. Swyngedouw (Eds.), The Post-political and Its Discontents (pp. 1-22). Edinburgh: Edinburgh University Press.

Wind Europe. (2018). Offshore Wind in Europe: Key Trends and Statistics 2017. Brussels: Wind Europe.

Žižek, S. (1999). The Ticklish Subject: The Absent Centre of Political Ontology. London: Verso. 
Open Access This chapter is licensed under the terms of the Creative Commons Attribution 4.0 International License (http://creativecommons.org/licenses/by/4.0/), which permits use, sharing, adaptation, distribution and reproduction in any medium or format, as long as you give appropriate credit to the original author(s) and the source, provide a link to the Creative Commons licence and indicate if changes were made.

The images or other third party material in this chapter are included in the chapter's Creative Commons licence, unless indicated otherwise in a credit line to the material. If material is not included in the chapter's Creative Commons licence and your intended use is not permitted by statutory regulation or exceeds the permitted use, you will need to obtain permission directly from the copyright holder. 